\title{
The role of territorial capital in building the competitive advantages of Podkarpackie Voivodeship
}

Abstract

In the discussion of regional development factors in recent years, more and more importance has been attributed to territory, locality, site specificity and endogenous resources, as evidenced on theoretical grounds by the concept of territorial capital (Camagni 2008) and regional, place-based policy. This article aims to identify the elements of territorial capital that play a key role in the process of changing the development path of an underdeveloped region - Podkarpackie - as well as ascertaining what consequences territorial capital has for development planning within regional policy. The research highlights the importance of the immobile and intangible development factors - a high level of social capital, extensive networks and the ability to cooperate - which have helped to eliminate the limitations resulting from the weakness of other factors (especially material factors, such as private capital and low GDP).

Keywords

Territorial capital • less developed regions • social and relational capital • place-based policy $\cdot$ Podkarpackie Voivodeship

(C) University of Warsaw - Faculty of Geography and Regional Studies

\author{
Anna Dąbrowska1, Jacek Szlachta ${ }^{2}$ \\ 'Department of Local Development and Policy, \\ Faculty of Geography and Regional Studies, \\ University of Warsaw, Poland \\ e-mail: a.dabrowska@uw.edu.pl \\ ${ }^{2}$ Department of Regional and Spatial \\ Development, Collegium of Socio-Economics, \\ Warsaw School of Economics, Poland \\ e-mail: jacek.szlachta@sgh.waw.pl \\ Received: 9 February 2017 \\ Accepted: 27 April 2017
}

Introduction

It may seem like a peculiar paradox that, in an era of globalization, when "distance means nothing" and "the places separated by these distances lose their meaning" (Bauman 2000, p. 25), so much attention is paid to the role of territory, locality, proximity, immobile development factors, and the local milieu. One of the concepts emphasized in theoretical approaches that perfectly reveals the specificity of a place, its components, and its strategic value in building competitive advantages, and furthermore, refers to a notable return of "territory" in public policies (the so-called territorialisation of public policies), is the concept of "territorial capital" (OECD 2001; Camagni 2008).

This article aims to verify whether the concept of territorial capital is useful in explaining the development factors of less developed regions using the example of the Podkarpackie Voivodeship in Poland. An attempt has been made to discover which components of territorial capital have played a key role in the process of changing the development path of Podkarpackie in relation to Camagni's (2008) factor classification, and what consequences territorial capital has for development planning within the regional policy of the regional government, and, to a lesser extent, for the programming of regional policies at the national and EU level.

Although the empirical study concentrates on Poland and a Polish region, it may be of wider importance for the other less developed regions in Poland, as well as regions in other EU countries.
The concept of territorial capital - theoretical framework

The concept of territorial capital combines two other concepts commonly found in the literature - "capital" and "territory". In economics, capital is traditionally determined to be an accumulation of tangible assets that, along with land and labour, constitutes a means of production that should multiply collected resources (Smith 2003). The concept of capital has recently been extended and is now used in relation to various resources such as human capital (Becker 1975; Schultz 1961), social capital (Bourdieu 1986; Coleman 1988; Fukuyama 1995; Putnam 1993), cultural capital (Bourdieu 1986), intellectual capital (Edvinson \& Malone 1997; Hudson 1993), relational capital (Camagni 1999), public capital (Romp \& De Haan 2007), natural capital (Costanza \& Herman 1992), and creative capital (Florida 2005).

The modern interpretation of space and territory also shows that the meaning of these concepts has evolved over time (Capello 2011; Szlachta \& Zaucha 2010). In classical economic theory, space was treated as a secondary factor to production, and its value was determined primarily in terms of the cost of location and distance (Przygodzki 2016). As evidenced by Pike, Rodriguez-Pose \& Tomaney (2007), among others, territory is nowadays a key development factor, not "solely a mere space" (Canzanelli 2001, p. 6), a container in which different social processes are played out (Hudson 2007), or just a receptacle for, or a manifestation of, outcomes (Scott \& Storper 2003). Among the numerous concepts incorporating the importance of territory in shaping development processes, territory is particularly heavily accented in endogenous theories of development: neo-Marshallian (referring to the static effects of 
agglomeration) and neo-Schumpeterian (relating to the impact of the concentration of economic activity on the development of innovation) (Zaucha et al. 2015, p. 108). ${ }^{1}$ Among these theories is the concept of territorial capital, which constitutes the theoretical framework for this article.

The concept of territorial capital was introduced by the OECD in 2001 in order to determine the specific resources of an area that represent the territory's competitive potential (cf. Wojnar 2013). Elements of territorial capital can include geographic location, unit size, production capacity, climate, traditions, natural resources, quality of life, and the benefits of agglomeration. It may also involve other factors such as "non-trade interdependence": understanding, customs and informal rules that enable economic entities to work together under conditions of uncertainty, solidarity, mutual assistance, cooperation, and sharing knowledge and ideas among people and businesses. It is also something intangible, 'hanging in the air'; an environment that involves the combining of institutions, rules, routine behaviours, people, producers, politicians and researchers, to create the conditions for creativity and innovation (OECD 2001, p. 15). The OECD (2001, pp. 15-16) indicates that "this 'territorial capital' generates a higher return for certain kinds of investments than for others, since they are better suited to the other area and use its assets and potential more effectively. This means that areas not only have Ricardian comparative advantages (i.e., they are more competitive because of the relative costs of factors of production), but also absolute advantages, for they have unique assets."

Camagni (2008) proposed a complex scheme for territorial capital according to which its individual elements could be classified in terms of competitiveness in consumption and the degree of materiality/tangibility (Figure 1). As a result, he recognised the following groups of factors: (a) public goods and resources, (b) intermediate, mixed-rivalry tangible goods, (c) private fixed capital and toll goods, (d) social capital, (e) relational capital, (f) human capital, (g) agglomeration economies, connectivity and receptivity, (h) cooperation networks, and (i) relational private services. The factors in the corner positions of the matrix (tangible and intangible public goods, and tangible and intangible private goods) are the traditional factors that build the potential of a region - the so-called "traditional square" (Figure 2A). Nowadays however, the competitive advantage of a territory is decided, above all, by resources of a relational and synergistic nature, combining hard with soft factors and public with private goods - the so-called "innovative cross" (Camagni 2008, p. 33) (Figure 2B).

The formulation of the concept of territorial cohesion is a specific attempt to translate the concept of territorial capital into the language of macroeconomic policy, and it places heavy emphasis on the significance of territorial factors in economic growth as well as incorporating specific spatial objectives into development policies (Zaucha 2014). Territorial cohesion is one of the fundamental goals of the European Union, but the term is still used in a fuzzy, ambiguous, and uncomprehensive way, by the political and technical institutions of the EU (Medeiros 2016, p. 22). This is why one of the biggest challenges is "to translate the concept of territorial cohesion into an concept which is easily understood and easily measured, as economic and social concepts are" (Medeiros 2016, pp. 5-6). This would not only allow us to reduce scientific misunderstanding among academics regarding the concept; but would also allow, primarily, for a more concrete and well-defined discussion about development and cohesion policies among politicians (Medeiros 2016, pp. 5-6).

${ }^{1}$ In terms of shaping development processes, the authors distinguish concepts covering intraregional specificity (including the above-mentioned endogenous theories of local development), treating territory as a determinant of the initial conditions of development, and spatial distance (Zaucha et al. 2015, p. 108).

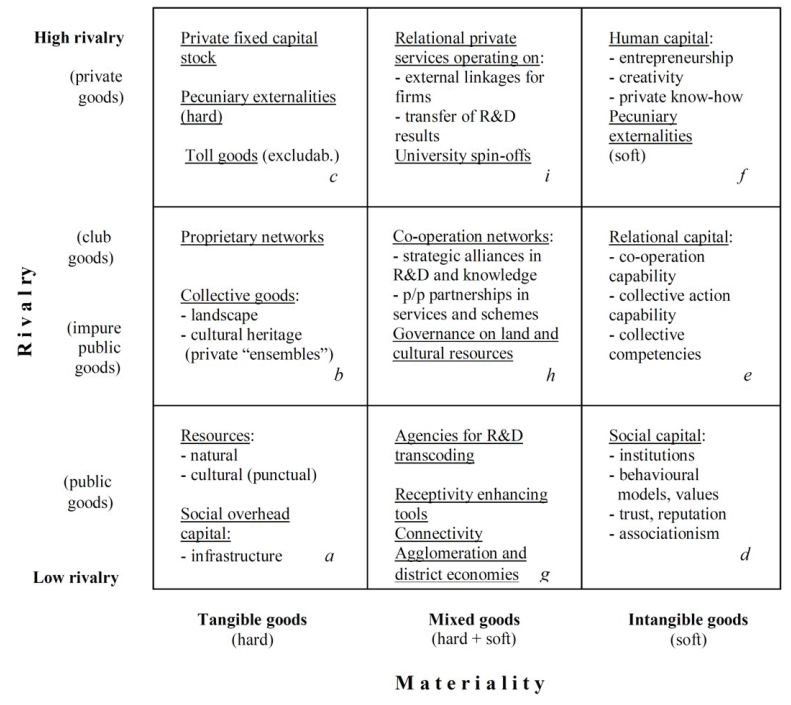

Figure 1. Components of territorial capital. Source: Camagni 2008, p. 38

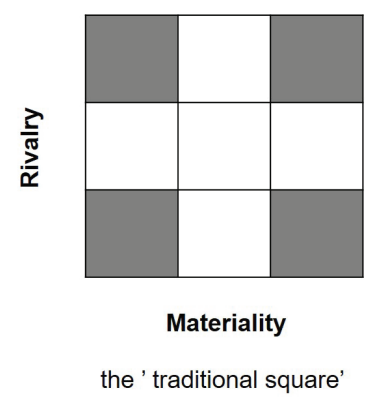

(A)

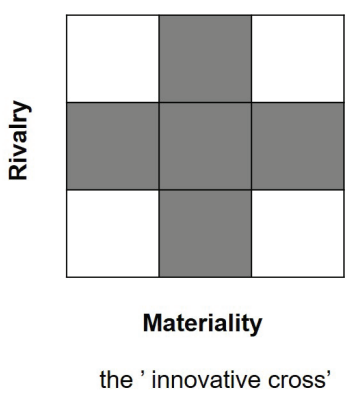

(B)
Figure 2. Components of territorial capital broken down into traditional factors (left) and innovative factors (right) or pleas add to the figure " $A$ " $n$ the left side and " $B$ " in the right side. Source: Camagni 2008, p. 37.

Formulating spatial strategies is very important not only for territorial cohesion, but also for a greater general coherence in EU policy (Faludi 2010). This seems even more valid in the case of the Third World, with its particularly strong inequalities and the constant conflict between the powers of global and local policies (Potter et al 2008).

\section{General characteristics of the study area}

Podkarpackie is one of sixteen Polish voivodeships created on 1 January 1999 under the local government reform. It is one of the poorest regions in Poland and in the European Union and, along with four other eastern Polish voivodeships, it receives additional support from the European Structural and Investment Funds, which is directed to the poorest regions in the EU. ${ }^{2}$ In 2013, the region's GDP was PLN 65 billion (3.9\% of Poland's GDP and $10^{\text {th }}$ place in the country). In terms of GDP per capita for the EU (calculated according to purchasing power standards - PPS), in 2011, Podkarpackie occupied $13^{\text {th }}$ position from the bottom (out of $268 \mathrm{EU}$ regions), with only one Polish region

${ }^{2}$ During 2007-2013, it was the Operational Programme "Development of Eastern Poland" 2007-2013, while the current financial perspective relates to the Operational Programme Eastern Poland 2014-2020. 
ranking lower (Lublin); its position has not changed since 2000, despite a real growth in the index of $73.4 \%$. Podkarpackie also faces other problems that are typical for peripheral regions: high unemployment, high levels of employment in agriculture while this sector also suffers from low economic efficiency, weak (though constantly improving) transportation accessibility, and highly diversified access to public services.

\section{Methodology}

The main method used for identifying the major factors that determine the development of Podkarpackie Voivodeship was individual, in-depth interviews with the main actors on the regional scene, ${ }^{3}$ supported by desk research analysis (of the voivodeship's strategic and operational documents) and statistical data analysis (Central Statistical Office and Eurostat). This analysis covers the last 15-20 years, including such milestones as the territorial reform of the country in 1998 and Poland's accession to the EU in 2004.

In this article, we focus in particular on the results of the qualitative research, which were used to assess which territorial capital factors determined Podkarpackie's development path to the greatest extent. Most of the empirical research, using the concept of territorial capital, is based on statistical analysis, although, as Camagni has indicated, there are serious difficulties involved in translating theoretical concepts into empirical analysis, and thus, into the practical application of models; this is due to the difficulty in measuring the intangible and therefore unobservable elements (Camagni, Caragliu \& Perucca 2011, p. 6). This problem is also highlighted in the Polish literature, which suggests a broader consideration of the qualitative methods of analysis (Zaucha et al. 2015, p. 163). We assume that, in Podkarpackie, it is the intangible factors - in particular, the social and relational capital - that play a key role, which is why the results of the qualitative research are particularly important.

Development factors of Podkarpackie Voivodeship research results

Quality of strategic thinking and the ability to cooperate in achieving developmental goals

A specific factor in the success of Podkarpacie is the workforce, who have developed through the creation of regional policy. Initially, they were not mature enough to take the initiative, but a steady reconstruction of consciousness occurred. We have witnessed the gradual evolution of strategic thinking among the public administration. They recognised the need to invest in the future and consequently the policy was implemented. (Władysław Ortyl, Marshal of Podkarpackie Voivodeship)

During the 1990s in Podkarpackie, a very positive expression of mature development planning was already observable in the city of Mielec (a community within Podkarpackie Voivodeship), which managed - almost perfectly - to handle the effects of the country's transformation and the need to restructure the WSK 'PZL-Mielec' factory (Dziemianowicz, Hausner \& Szlachta 2000, p. 44-45). ${ }^{4}$

The high quality of the strategic thinking in the former Voivodeship of Rzeszów is indicated by the fact that, after the

${ }^{3} \mathrm{~A}$ total of 15 in-depth interviews were conducted with the Marshal of Podkarpackie Voivodeship, the Mayor of Rzeszów, and representatives of the following institutions: the Office of the Marshal of Podkarpackie Voivodeship (the Department of Regional Development), Rzeszów Regional Development Agency (the Investor Service Centre, the Centre for Organisational Training and International Cooperation, the Centre for Technology Transfer, Innovation and Computerisation, and the Centre for Enterprise Development), Mielec Euro-Park Special Economic Zone, the "Aviation Valley" cluster, the cluster of Eastern Poland IT companies, the University of Information Technology and Management in Rzeszów, and the Centre for Innovation and Technology Transfe at Rzeszów University of Technology.

${ }^{4}$ Unfortunately, there were cities in the vicinity of Mielec where a mature, consistent approach to development planning was hard to find, where the attitude of the local authorities was described by respondents as "demanding and super-powered", characterized by passivity ("they stayed in the blocks, waiting for intervention from the outside", "they missed their chance") and orientation towards the past ("staring into the past, mourning the loss of their previous position").
Poland's territorial reform in 1998, Podkarpackie Voivodeship worked very well at creating the new documents that enabled the adoption, in 2000 , of the country's first regional development strategy - the Development Strategy of the Podkarpackie Region for the period 2000-2006 (Dziemianowicz, Hausner \& Szlachta 2000, p. 46). Work on the first Regional Innovation Strategy proceeded similarly smoothly, and was adopted in December 2004 (the fifth in Poland). The building of strategic documents for Podkarpackie Voivodeship by social means can be evaluated as positive, with strong commitment and cooperation between the different actors, which included Rzeszów University of Technology, the University of Rzeszów, the University of Information Technology and Management in Rzeszów, and Rzeszów Regional Development Agency SA.

Policies implemented consistently with widespread social agreement

The widespread agreement about the roles of local and regional leaders, as well as strategic thinking, seems to have played a significant role in building the region's potential, as demonstrated by the following statement: "essential to the development of the region are leaders who formulate visions and have the ability to communicate with the public (...); the professionalization of public management and strategic thinking are necessary" (respondent's statement). In addition, an expression of the quality of strategic management is the ability to focus activities on selected development priorities (strategic records in documents and consistently implemented regional policy), as well as the conviction that peripheral regions need to embrace innovation and find innovative ways to deal with traditional problems.

Although the region suffers from depopulation, emigration and brain drain, the capital of the voivodeship is a strong centre for training staff specialized in the main industries of the region

Rzeszów has great potential in the field of training highly qualified personnel. The city has 16 higher education institutions (including the University of Rzeszów, Rzeszów University of Technology, and the University of Information Technology and Management in Rzeszów), which educate 65,000 students (with 353 students for every 1,000 inhabitants, the city has the highest such ratio among European cities). The capital of the region is also unique at the national scale as a training centre for civil aviation pilots, as well as being a strong training centre for IT specialists (one in ten IT specialists in the country are graduates of Rzeszów University of Technology).

Developed social capital is manifested in a high level of trust in neighbours

Numerous studies have shown that the residents of Podkarpackie Voivodeship stand out from other regions due to the high level of trust they have in their neighbours (Czapiński \& Panek 2015), as well as a greater tendency to establish relationships within small local communities, which is evidence of a high level of bonding social capital. Admittedly, high levels of bridging (not bonding) capital are generally recognised as being responsible for the quality of cooperation between companies and various institutions, but in the case of Podkarpackie, there are many signs of highly developed cooperation stretching far beyond familial and neighbourhood relationships, with perhaps the best example being the clusters that function in the region.

A developed network of cooperation between businesses and other institutions through cluster initiatives

According to an inventory carried out in 2015, with its 12 clusters, bringing together almost 500 entities in total, Podkarpackie Voivodeship was one of the national leaders 
in terms of its functioning initiatives (after the voivodeships of Silesia, Mazovia and Wielkopolska) (Buczyńska, Frączek \& Kryjom 2016, p. 17). ${ }^{5}$

Leading initiatives are part of the smart specializations of the voivodeship

Of the existing clusters, special attention should be paid to "Aviation Valley" and the "KlasterIT" IT Firms Cluster, which operate in two of the region's strongest industries, aviation and $\mathrm{IT},{ }^{6}$ which are identified by the voivodeship as the region's smart specializations:

- aviation and aerospace as leading specializations, based on the aviation industry's long traditions in the region, along with a concentration of up to $90 \%$ of Polish aviation manufacturing in the Podkarpackie area. ${ }^{7}$

- IT and telecommunications as support specializations, of a horizontal nature, necessary for the dynamic development of the two leading specializations.

In 2015, the Aviation Valley Cluster numbered 149 members (ed Darecki 2015, p. 22) and is not only noted as one of the first cluster initiatives in Poland, but above all, a model example of bottom-up cluster formation. The Aviation Valley agreement concluded in $\mathbf{2 0 0 3}$ was an example of the positive cross-linking of all the entities interested in the development of the industry and the institutionalization of cooperation, which was already well developed ("the Aviation Valley Cluster is a creative continuation of the Central Industrial Region (COP) idea, a kind of COP-bis" (ed Darecki 2015, p. 10)). Podkarpackie is even known as the "Polish Toulouse" or "Polish Montreal", in reference to world standards in the aviation industry that have highly developed cluster structures ("Aerospace Valley" Cluster and Aero Montreal) (Regional Innovation Strategy... 2015, p. 34)

The strong position of the R\&D sector - the key role of the private sector

The corporate sector plays a key role in the development of cluster initiatives, as well as a dominant role in R\&D initiatives. Podkarpackie is distinguished, in national terms, by its high proportion of expenditure on R\&D in relation to GDP $(1.2 \%$ in 2014, the third highest in Poland, $0.9 \%$ ), but above all by its much greater proportion of private sector R\&D staff $(70 \%$ of R\&D staff came from the corporate sector in 2014; the second highest in the country was $34 \%$, while the national average was $28 \%$ ) and the predomination of private financing for innovation activities (R\&D activities were $76.7 \%$ funded by the corporate sector in 2014 , while the national average was $47 \%$ ).

Development factors of Podkarpackie Voivodeship - discussion

The level of development of Podkarpackie Voivodeship is relatively weak, as assessed by measures relating to the creation of national income and referring to hard development

5"Aviation Valley", Innovative Health and Tourism Cluster "Pearl of Eastern Poland Spas", Carpathian Tourism Cluster, Eastern Poland IT Firms Cluster, Photonics and Fibre Optics Cluster, Light and Ultralight Aviation Cluster, "Podkarpackie Flavours" Cluster, POLIGEN Plastics Processing Cluster, KLASTAL Welding Cluster, Podkarpackie Renewable Energy Cluster, Eastern Municipal Cluster, KOM-CAST Eastern Foundry Cluster (Buczyńska, Frączek \& Kryjom 2016, pp. 70-71).

${ }^{6}$ The Rzeszów sub-region clearly stands out from the other sub-regions in Poland in terms of the development of the ICT sector. The dynamic employment growth and increase in turnover in ICT companies observed during the period 2005-2011 places the Rzeszów sub-region at the forefront of European sub-regions (second and third place, respectively, out of 1,307 European sub-regions (NUTS3) (cf. de Prato \& Nepelski 2014, pp. 98 and 102).

${ }^{7}$ The second ranked specialization is quality of life (Regional Innovation Strategy. 2015, p. 37).

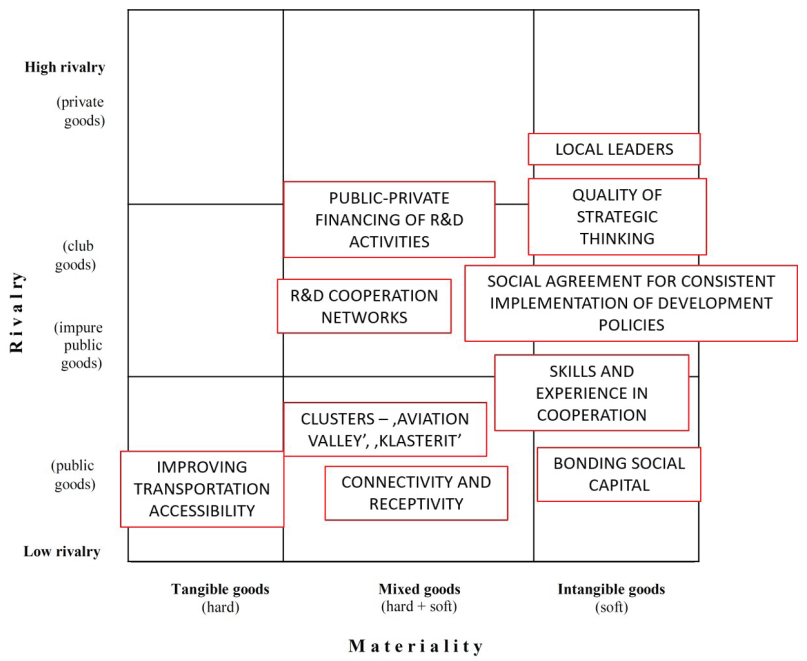

Figure 3. Developmental factors of Podkarpackie Voivodeship in the territorial capital model. Source: own elaboration.

factors. However, the growing importance of soft development factors makes the region's actual position much more favourable. In relation to Camagni's (2008) concept of territorial capital, when analysing the main factors that have determined the development of the region in recent years, the following should be noted:

- $\quad$ the development has been built on strong foundations and existing traditions, using the territory's existing endogenous resources (infrastructure, working staff, the industrial image of the region, and the R\&D potential), and did not occur in a vacuum;

- immobile and intangible development factors, including social and relational capital, have played a particularly important role in the development of the voivodeship. The high level of social capital, extensive networks, and the ability to cooperate, are all factors that have helped break the limitations resulting from a weakness in other factors, such as capital resources, cf. Figure 3.

- regional (and local) authorities had a special role to play in relation to development policies based on territorial capital through the effective and, above all, consistent implementation of development policies.

\section{Conclusions and implications for regional policy}

In the context of development planning, it is significant that the territorialisation of public policies and a greater consideration of territorial potentials are of increasing importance for the effects of public intervention (territory matters) (Szlachta 2015, pp. 3-4). The determining factor in obtaining additional benefits is not only the level of the territorial capital's development, but also its structure - that is, its components (Fratesi \& Perucca 2014).

Podkarpackie regional policy should be oriented, above all, towards the further strengthening the metropolitan functions of Rzeszów as a generator of development processes, supporting sub-regional centres, utilizing the systematically improving territorial accessibility, eliminating duality in the spatial structure, and utilizing relations with Ukraine. The transfer of high territorial capital to the parameters of real socio-economic processes is of key importance. Improving the region's development trajectory is possible using the unique potential of industry and related services, the strength of the R\&D sector, and the region's importance as a scientific and educational centre, including within the international arena. 
Acknowledgements

This paper is based on the result of the "Changing innovation processes models: A chance to break out of path dependency for less developed regions" research project funded by the National Science Centre, Poland; grant number DEC-2014/13/B/ HS5/03612. The grant was awarded to the University of Warsaw, Faculty of Geography and Regional Studies.

\section{References}

Bauman, Z 2000, Globalizacja, PIW, Warszawa.

Becker, GS 1975, Human capital: A theoretical and empirical analysis, with special reference to education, 2nd edition, Columbia University Press, New York.

Bourdieu, P 1986, 'The forms of capital', in Handbook of Theory and Research for the Sociology of Education, eds $\mathrm{J}$ Richardson, Greenwood Press, New York, pp. 241-258.

Buczyńska, G, Frączek D \& Kryjom, P 2016, Raport z inwentaryzacji klastrów w Polsce 2015, Polska Agencja Rozwoju Przedsiębiorczości, Warszawa.

Camagni, R 1999, 'The city as a milieu: appplying GREMI's approach to urban evolution', Revenue d'Economie Régionale et Urbaine, vol, 3, pp. 591-606.

Camagni, R 2008, 'Regional Competitiveness: Towards a Concept of Territorial Capital', in Modelling regional scenarios for the enlarged Europe, eds R Camagni, R Capello, B Chizzolini \& U Fratesi, Springer, Berlin, pp. 33-48.

Camagni, R, Caragliu, A, \& Perucca, G 2011, Territorial capital. Relational and human capital, Politecnico di Milano. Available from: <http://www.grupposervizioambiente.it/aisre/ pendrive2011/pendrive/Paper/Camagni_Caragliu_Perucca. pdf $>$ [10.01.2017].

Capello, R 2011, 'Location, Regional Growth and Local Development Theories', Aestimum, vol. 58, pp. 1-25.

Coleman, JS 1988, 'Social capital in the creation of human capital', American Journal of Sociology 94, pp. 95-121.

Costanza, R \& Daly, HE 1992, 'Natural Capital and Sustainable Development', Conservation Biology, vol. 6, no. 1, pp. 37-46.

Czapiński, J \& Panek, T (eds) 2015, Diagnoza społeczna 2015. Warunki i jakość życia Polaków, Rada Monitoringu Społecznego, Warszawa.

Dolina Lotnicza. Strategia działania i rozwoju Stowarzyszenia Grupy Przedsiębiorców Przemysłu Lotniczego „Dolina Lotnicza" 2015, opracowanie zespołu pod kierownictwem prezesa zarządu SGPPL „Dolina Lotnicza” Marka Dareckiego, Rzeszów.

Darecki, M (ed) 2015, Dolina Lotnicza (Aviation Valley). Strategia działania i rozwoju Stowarzyszenia Grupy Przedsiębiorców Przemysłu Lotniczego „Dolina Lotnicza”, Rzeszów.

Dziemianowicz, W, Hausner, J\&Szlachta, J2000, Restrukturyzacja ośrodków monokulturowych na przykładzie Mielca, IBnGR, Gdańsk.

Edvinsson, L \& Malone MS 1997, Intellectual Capital, Piatkus, London.

Faludi, A 2010, Cohesion, Coherence, Cooperation: European Spatial Planning Coming of Age?, Routledge, New York.

Florida, R 2005, Cities and the Creative Class, Routledge, New York.

Fratesi, U \& Perucca, G 2014, 'Territorial Capital and the Effectiveness of Cohesion Policies: an Assessment for CEE Regions', Investigaciones Regionales, vol. 29, pp. 165-191.

Fukuyama, F 1995, Trust: The Social Virtues and the Creation of Prosperity, Free Press, New York.
Hudson, W 1993, Intellectual caiptal: How to build it, enhance it, use it, John Wiley \& Sons, New York.

Medeiros, E 2016, 'Territorial Cohesion: An European Concept', European Journal of Spatial Development, vol. 60. Available from: < http://www.nordregio.se/Global/EJSD/Refereed articles/refereed60.pdf>. [19.04.2017].

OECD 2001, Territorial Outlook. Territorial Economy, OECD, Paris.

Pike, A, Rodriguez-Pose, A \& Tomaney, J 2007, 'What kind of local and regional development and for whom?', Regional Studies, vol. 41, pp. 1253-1269.

Potter, R, Binns, T, Elliott, J, Smith D 2008, Geographies of Development. An Introduction to Dvelopment Studies, Third Edition, Pearson Education Limited, Essex.

de Prato, G \& Nepelski, D 2014, Mapping the European ICT Poles of Excellence: The Atlas of ICT Activity in Europe, JRC Working Papers JRC85353, Directorate Growth\&Innovation and JRC-Seville, Joint Research Centre.

Przygodzki, Z 2016, 'Kapitał terytorialny w rozwoju regionów', Acta Universitatis Lodziensis, Łódz, vol 2, pp. 83-97.

Putnam, RD 1993, Making Democracy Work: Civic Traditions in Modern Italy, Princeton University Press, Princeton.

Regionalna Strategia Innowacji Województwa Podkarpackiego na lata 2014-2020 na rzecz inteligentnej specjalizacji 2015 (RIS3), 2015, Rzeszów, [Regional Innovation Strategy... 2015].

Romp, W \& De Haan, J 2007, 'Public capital and economic growth: a criticl survey', Perspektiven der Wirtschaftspolitik, vol. 8(S1), pp. 6-52.

Schultz, TW 1961, 'Investment in Human Capital', The American Economic Review, vol. 51, no. 1, pp.1-17.

Smith, A 2003, The Wealth of Nations: An Inquiry into the nature and Causes of the Wealth of Nations, Bantam Classics, New York, (first published in 1776).

Szlachta, J 2015, Recommendations for applying territorial cohesion concept for conducting development policy. Territorial aspects of public policies, Working Papers no. 016/2015, Institute for Development, Sopot.

Szlachta, J \& Zaucha, J 2010, A new Paradigm of the EU regional development in the context of the Poland's National Spatial Development Concept, Working Papers no. 001/2010, Institute for Development, Sopot.

Wojnar, K 2013, 'Ocena oddziaływania na terytorium jako instrument polityki przestrzennej', in Terytorialny wymiar rozwoju. Polska z perspektywy badań ESPON, eds A Olechnicka \& K. Wojnar, Wydawnictwo Naukowe Scholar, Warszawa, pp. 12-30.

Zaucha, J 2014, Evolution, essence and measurement of territorial cohesion, Working Papers no. 001/2014, Institute for Development.

Zaucha, J, Brodzicki, T, Ciołek, D, Komornicki, T, Mogiła, Z, Szlachta, J \& Zaleski, J 2015, Terytorialny wymiar wzrostu i rozwoju, Difin, Warsaw. 